\title{
INDUSTRIAL HERITAGE IN SOUTHWEST SARDINIA: THE CASE OF THE MONTEPONI MINE IN IGLESIAS
}

\author{
ROSSELLA PUTZOLU \\ Department of Architecture and Environmental Engineering, University of Cagliari, Italy.
}

\begin{abstract}
This article aims to introduce an industrial heritage site in Southwest Sardinia, in the neighbourhood of Iglesias, both its past and current features: here the Monteponi Mining Company exploited minerals extensively and constructed mining buildings and infrastructure since the 1850s. The remains of this mining heritage, consisting of buildings, houses, slag heaps, services and machineries, are still clearly visible and they show both the important role that those buildings have held since the mid-19th century and the negative effects from abandonment and degradation that have affected them since they were closed or dismantled in the 1960s. The Monteponi Company, founded in Genoa in 1850, rented the area near Iglesias and started to improve it and to equip it with new buildings and services that are beautiful exemplars of Neoclassical and Eclectic architecture, where engineering technique is combined with a sensibility for decorative details. This modernization went on until the 1920s with a proliferation of pits, galleries, workshops, foundries, a railway station with its own inclined plane, washes, residential buildings, chemical plants, forges, carpentry, and so on. The methodology of the article is based on research of archived sources, publications and the Society's administrative records in order to illustrate the historical scenario and the architectural features of this case study and to compare them with cartographies, building projects and schemes both from the past and the present, underlining the importance of saving this heritage and its values.
\end{abstract}

Keywords: abandoned, building technology, construction history, Eclecticism, Iglesias (Sardinia), infrastructure, mining heritage, Monteponi Company, Neoclassical Architecture, safeguard.

\section{INTRODUCTION}

This article concerns the history and development of a Sardinian mine, Monteponi, an important example of mining heritage currently almost abandoned and in ruins, that must be preserved from total destruction and saved for its historical and cultural value. This site is indeed a milestone of mining history in Sardinia and in the Construction History of industrial building from the 19th century thanks to the work of foreign and Italian mining engineers, employees of the Monteponi Company, who built up the site from the 1850s to the 1920s.

The presence of mining activities, both on a regional and local scale, reveals itself as an important factor of urban development, landscape morphology and modifications. Moreover, mining sites are an essential part of the history of those territories. Either in open air or in subsoil, mining exploitations have featured Sardinia for centuries, as like as many countries in Europe, with peculiar signs such as terracing, dumps, mining towns and villages, industrial and transport infrastructure that collect around a site - or sites on a territorial scale. Social and urban implications are also remarkable since workers, managers and employees involved with the mines usually settled in the neighbourhoods or inside the mine complex, which ended up being both an industrial setting and a residential area in a certain sense with its proper trades, educational and sanitary services, housing and Bureaux.

Unfortunately, both in this case and in many European mining areas, the ending of mining explorations led to a progressive abandonment of structures such as chimneys, pits, foundries, factories, and so on, and today these 'objects' demand renewed attention and repair in order to prevent their collapse and to give them back to their communities in perspective of restoration coupled with reuse. 


\section{FROM THE FIRST EXPLOITATIONS TO THE GOLDEN AGE OF SARDINIA'S MINES}

In order to understand the history of this case study, we need to briefly introduce how mining activities started and developed in Sardinia. Besides the first exploitations and extractions of minerals dating to the Phoenicians, the Romans and the Byzantines [1], the greatest period for mining industry in Sardinia dates back to the occupation and dominion of the Pisa government, which settled on the Island at the end of the 1250s. For 70 years, it was almost entirely occupied by Genoan and Pisan governors, the latter of which particularly took over the southwest part of the Reign [2]. Between 1257 and 1272, there was the settlement by the Della Gherardesca Family of a new town, called Villa di Chiesa (the town of the Churches), that became one of the most important mining centres in Sardinia: the purpose of its settlement was the exploitation of deposits of galena and lead, located in the area of Monte Paone (the ancient name for Monteponi) just outside the town. Thanks to the prosperity and earnings from mining activities, Pisan governors turned Villa di Chiesa into a flourishing town, with a mint, foundries, numerous churches, fortified walls and a Cathedral [3] and a compendium of municipal and mining laws called the Breve which, along with the one from Massa Marittima, represents one of the most important administrative and mining codes of that period. The Breve is indeed a key to understanding the development and the management of mining centres and the discipline of the exploitations, from the Pisan dominion rule to the Aragons, as it contains numerous valuable explanations and details concerning techniques, tools, characters and roles involved in running a mine. Moreover, it explains where they excavated to extract and to melt metals from Monte Paone, the most exploited area was on the top of the mountain, which was called Cungiaus $[4,5]$.

\subsection{Catalan-Aragon period: from the 14th to 18th centuries}

After the 70-year dominion of Pisa and Genoa, Sardinia was conquered by the CatalanAragon army in 1323. Infante Alfonso IV invaded the Island, starting from the southwest coast, and quickly conquered the principal towns, such as Villa di Chiesa and Cagliari, while Arborea and Sassari, held by the Doria and Malaspina families, were put under vassalage. Despite several uprisings, the Aragon and Catalan kingdoms finally gained control of the entire Sardinian territory by the end of the 15th century [6]. Concerning mining activities, the Catholic Kings modified the laws on excavations, introducing a distinction between the property of soil and the property of mines: the first belonged to the Crown, the latter to a renter in return for an annual fee. The result was numerous concessions given by the Kings for the exploitation of Sardinian mines, although the former Villa di Chiesa - named, definitively, Iglesias in Spanish - was run by the State itself to extract lead and silver in the same Cungiaus region in Monte Paone.

Mines were still considered a state property until the 17 th century and there were renters in many parts of the Island; during this period, we find the names Monte Paone and Monte de Ponis, referring to the Monteponi mine in Iglesias, in several charts from the National Archive of Cagliari [7].

\subsection{The Savoy era}

At the beginning of the 18th century, the rule of Sardinia passed to the Piedmont family of Savoy thanks to the London Treaty in 1718 and the Hague Treaty in 1720: the Island then became a proper autonomous state, although it was still part of the House of Savoy along 
with other states of the same family. Mines were under the jurisdiction of Viceroys and were still considered state property so they were licensed for 20 years to the society, Nieddu \& Durante. By the 1740s they were passed on to the Swedish Counsel Gustav Mandel and then to Pietro Belly, an artillery officer. In those years the main works were done in the Monteponi and Montevecchio mines with the introduction of the black powder by German experts to speed up the excavations [8-10]. Under Belly's management there was a reprise of exploitations in several mines of the Island but, due to climate conditions, high costs of maintenance, technical difficulties and hazardous investments, the situation of the Sardinian mines did not go as expected and Belly went bankrupt in 1782.

In the last decades of the 18th century, there was no more news about mining exploitations and most of the mines were closed or abandoned.

\subsection{The 19th century}

During the first 30 years of the new century there was no relevant news about mining exploitations in Sardinia, except for the arrival of engineer Francesco Mameli [11] as a mining inspector to report the necessary innovations to be made. In Monteponi, the only changes were a reprise of excavations in two regions, the San Vittorio and the Saint Real, and the linking of three new galleries to those regions [12]. Few concessions were given for exploitations in the other mines and it was not until political and economic conditions changed that more chances for exploitation were granted for the Sardinian mines. Indeed, in 1847, the Kingdom of Sardinia joined the other States of Piedmont and Savoy through a union called the 'Perfect Fusion', which gave it the right to rent almost 1,000 acres of land - presumed to be rich in deposits - for a long period of time in return for a fee, without the opposition of the landowners, thanks to the fact that the state owned the subsoil [13].

This achievement was the beginning of a 'mine rush', resulting in an increase of licences and the arrival of foreign companies (from Belgium, France and Germany). Giovanni Antonio Sanna was granted the first concession with which he started work in the Montevecchio mine. Along with the Monteponi, it would become one of the most important mining works in the area.

This period featured great investments in the territory: the creation of buildings, infrastructure, transport routes, railways and mining towns that developed as long as the mines prospered [14].

In 1850 there was another important event: the banker Paolo Antonio Nicolay founded the Monteponi Company in Genoa along with other partners and he obtained a 30-year long concession to exploit the Monteponi mine. During this time, the Sardinian mines, particularly the Monteponi and the Montevecchio, thrived and saw their highest production standards ever [15]. Technological innovations and new discoveries - such as calamine deposits - meant a more scientific approach to the exploitations, with a progressive mechanization and improvements of factories and pits, metallurgical workshops and the introduction of steam-powered engines, motors, electric energy, and so on.

\section{THE MONTEPONI MINE: FROM THE 1850S TO THE BEGINNING OF THE 20TH CENTURY}

The first manager of the mine was the Hungarian engineer Julius Keller who had trained in the mines of the Austro-Hungarian Empire and was therefore aware of the improvements needed to modernize the mining work. 
He started with an accurate survey of deposits and underground works and he opted for more rational criteria to conduct the excavations. He introduced tracks inside the galleries to speed up the transportation of minerals to avoid the accumulation of stocks, and he built a washing plant to treat minerals from Saint Real and San Vittorio areas. Finally, he turned the former jail (built by Belly in the 1780s to house the prisoners working as miners) into a building to host workers and miners when they were off-duty and to protect them from bad weather. Keller also suggested constructing a foundry to melt the lead that was left untreated in order to increase earnings but Nicolay and his partners were not as optimistic and thus Keller was dismissed in 1856 due to the continuous disagreement between them [16].

\subsection{The Pellegrini era}

Among the figures that brought Monteponi to its highest levels of technical and architectural modernity is Adolfo Pellegrini, who became manager in 1861 at the young age of 23.

Besides two new galleries, made possible thanks to the accurate surveys by Keller, Pellegrini built new facilities such as the Delaunay Hospital, a washing plant in the San Severino area and a workshop [17]. But his most important works in the first years of activity were the Vittorio Emanuele Pit, designed by Franz Stiglizt and built in 1863 to house the dewatering pumps; the new House of the Manager, the Bellavista (i.e. Beau view) designed by Pellegrini himself in 1865; and the Sella Pit, a huge complex that housed dewatering pumps, workshops, a carpentry and a foundry of cast iron [18]. This building is clearly appreciable for its formal and architectural features that underline the importance of Eclectic language, Classical forms and the co-existence of structure and decoration in industrial buildings from the post-Unit period in Italy. In the same years, the discovery of calamine deposits in the Cungiaus area, already exploited by Romans and Pisans, launched a new programme of excavations and treatment of zinc in Monteponi, with a huge funnel-shaped hole in the top of the hill.

Pellegrini then solved another complication linked to the transportation of minerals from the mine to the embarkation port, located on the southwest coast, from where they were sent to the main foundries and metallurgical centres in Europe. From 1871 to 1875 he built a railway from the mine to the coast in order to avoid the use of sailboats which would suffer delays and interruptions due to weather conditions. Moreover, in order to link the railway station located in the lowest part of the mine to the main levels (near the galleries and pits), Pellegrini built a large inclined plane made of bricks and stones and a huge arch leaping the road at mid of the hill, with trucks moved by a crane and wagons that went up and down to deliver minerals and general goods [19, 20].

In 1867, the Monteponi built its own foundry near Iglesias but a proper metallurgical system was not installed in the mine until the 1890s.

\subsection{From the 1870s to the 1900s: technical development and engineering masterpieces}

After Pellegrini left in 1875, the second main figure of Monteponi's 'golden age' is Erminio Ferraris, a well-prepared, forward-looking engineer. Firstly, he had to face the problem of dewatering issues, which had not been solved by Pellegrini despite the building of the Vittorio Emanuele and Sella Pits. Therefore Ferraris proposed that the Company construct a dewatering gallery to link the main levels of the mine - starting at Vittorio Emanuele Pit - to sea level in order to pump water directly into a marshland behind the coast [21]. This proposal also gave Monteponi an added advantage, which was the possibility of purchasing the mine instead of continuously renewing the licence since the costs to build a dewatering 
gallery would have been too expensive without the guarantee of exploiting the mine for a long period. Finally, in 1879, the Monteponi Company bought the mine with the commitment to build the gallery.

This masterpiece of hydraulic engineering - 4,975 m long and 1\%o sloping - was started in 1880 and completed only in 1908-1909 due to great difficulties involving the demolition of mountainous rocks and the presence of water during the excavation of two auxiliary pits that were designed to speed up the construction work. The gallery, dedicated to King Umberto I, still exists today and it opens into the sea by a canal passing through the marsh [22]. The automatic hole punchers, patented by Ferraris himself to speed up the operations, received awards at the Universal Exhibition in Paris in 1878 and for the first time, electrical energy was used to supply the machineries.

Furthermore, Ferraris took into great consideration the possibility of starting a metallurgical plant to melt and mould minerals directly in loco instead of sending them abroad. Since 1879, Ferraris started a real transformation of Monteponi's factories, turning the existing washes into mechanical ones and building new washes to treat lead, galena and zinc minerals. The first was the Vittorio Emanuele, followed by the Sacchi and Pilla Wash in 1879-1880 located in the railway area (called Scalo) - and then the most important one, the Calamine Wash that was built in 1887 [23, 24].

The Calamine Wash was indeed the greatest treatment plant for zinc minerals extracted in Cungiaus, where Ferraris installed one of his most famous inventions, the oscillating table that parted zinc minerals from inert substances. Along with this plant, Ferraris designed and built the Magnetic Wash, where he installed his patented magnetic sorting machine that used magnetic forces to attract and separate magnetic oxides from zinc minerals. Both Calamine and Magnetic Washes were near the crane building of the inclined plane in order to facilitate the transport of minerals from the main levels to the railway station. In 1893, there was the final transformation of the Sacchi and Pilla Wash into a new plant, technologically advanced, called the Mameli Wash which is still visible today [25, 26].

On the metallurgical front, Ferraris was perfectly aware that Keller's aims about the selfproduction of melted and moulded products would have been a great achievement and an economic advantage for the company. Therefore, at the beginning of the 1890s, he started the bronze and cast iron foundries which supplied the necessary spare parts for machinery by melting them directly into wooden moulds made in the carpentry workshops. However, the greatest foundry was finally completed in 1894 near the Vittorio Emanuele Pit to melt lead and silver. This plant, variegated in its volumes and buildings, was fuelled with coal from Monteponi's deposits near the mine and it manufactured a continuous production of silver and lead bars, ready to be sold and exported [27]. Thanks to these innovations, the Monteponi Company received awards at the Universal Exhibition of Paris in 1900 as well as sweeping and positive reviews, particularly for Ferraris' patented machineries. A few years later, in 1906, electricity was accessible in all the metallurgical plants and 2 years later the dewatering gallery, Umberto I, finally arrived at its intended destination, the Vittorio Emanuele Pit.

\subsection{The declining phase: $1914-1928$}

In 1907, Ferraris passed on the management to engineer Francesco Sartori, who had to face the difficulties of the war period: a general crisis of the mining trade, restrictions, increase of costs and lack of personnel. Despite these conditions, Sartori built a new plant in 1914 to produce white oxide of zinc, intended as an optimal naval paint thanks to the presence of lead [28, 29]. 
In 1926, the new manager, Andrea Binetti, assigned to Prof. Livio Cambi the project of a huge electrolysis plant to treat zinc minerals: this complex replaced the former Vittorio Emanuele mechanical Wash and it featured large spaces to house tubs, pipes, machinery and so on $[30,31]$.

The last episode of note in this period was the construction of a factory of sulphuric acid in the Scalo area to supply acid for the electrolysis plant. Since then, very few innovations or implementations have been made in the Monteponi mine and, unfortunately, most of the plants and structures were dismantled in the 1960s and many parts were sold as scrap metal, such as the inclined plane and the railway.

\section{MONTEPONI'S MINING HERITAGE: CONSTRUCTIVE AND ARCHITECTURAL FEATURES}

In light of these facts, we can now make some considerations about the main buildings of the mine: under the impulse of the new constructive culture of the 19th century, the spread of scientific and innovative building techniques from Europe, and the introduction of new materials such as steel and concrete, the expressive languages in Monteponi changed throughout its history, according to architectural choices and building purposes. If, in the first years of exploitations in the late 18th and first half of the 19th centuries, buildings were no more than places useful to the excavations and to workers, after the arrival of foreign engineers - who were educated abroad or in northern Italian academies - there was a strong change in formal and constructive features. For example, the Saint Real Wash, built by Keller in 1853, is made with a simple tiled roof, irregular stone masonries and cut stone anchoring [32]. Only 10 years later, there is a significant progression in the architectural concept of the buildings. The Vittorio Emanuele Pit, shown in Fig. 1, and the Bellavista Villa are examples of a union between Modern and Eclectic styles, beginning with their volumetric and material conception: the first features a high and narrow space placed over a podium, with a huge opening on the main façade that looks like the access to a 'sancta sanctorum of modernity' whose inner cell is hidden from the outside; on the main façade there are typical Neoclassical elements, such as arches, Doric pilasters, a 2.75-m-high trabeation over which there was a pavilion roof. On both sides there are arched-windows and oculi to let the light flood inside. The main volume originally dominated by its high chimney, which underlined its productive and essential role.

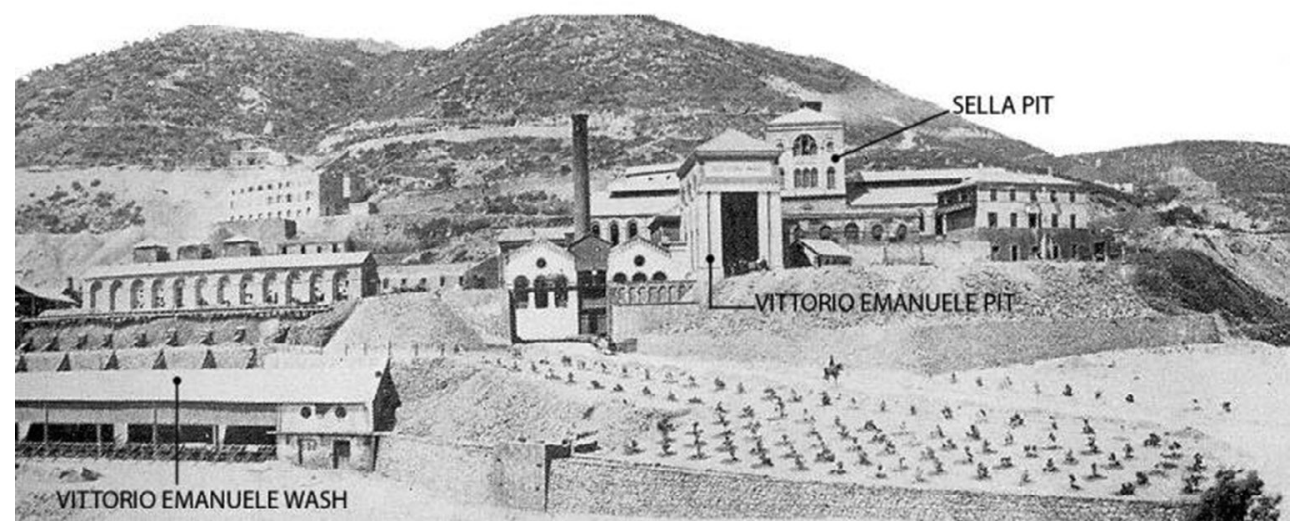

Figure 1: 1875 Sella Pit, Vittorio Emanuele Pit and Wash (Iglesias Municipal Archive). 


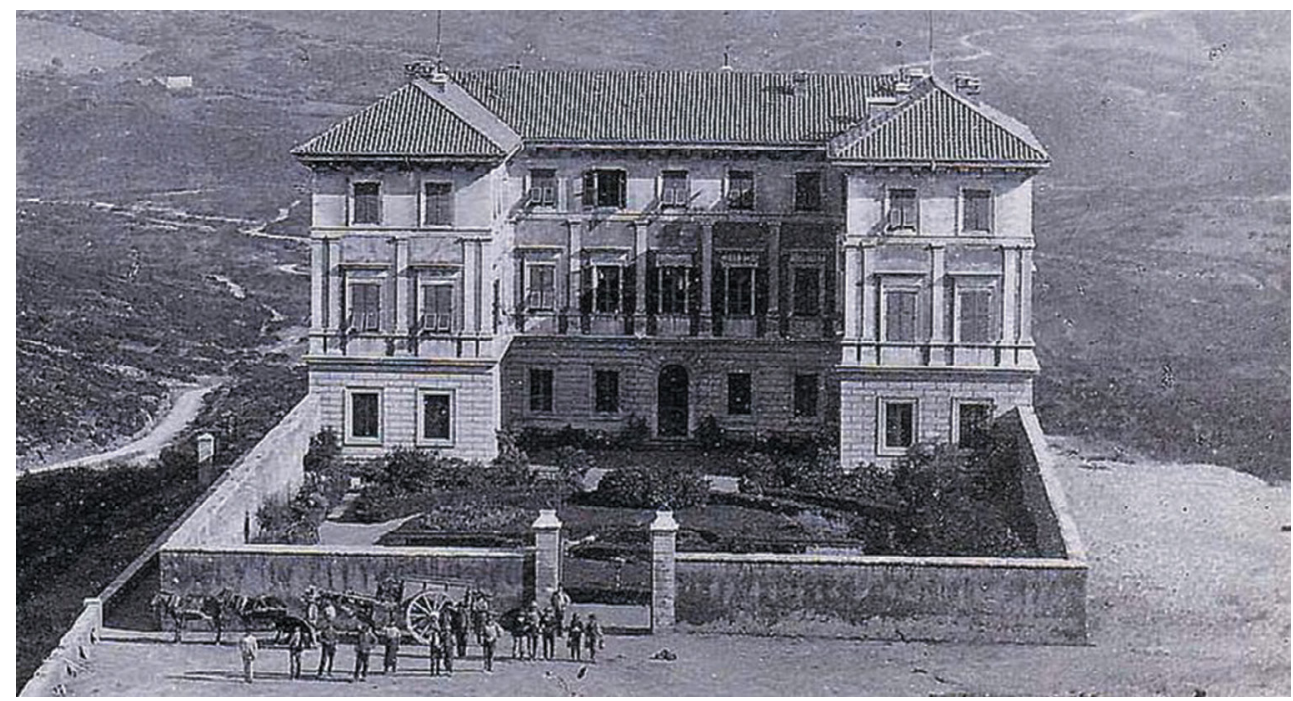

Figure 2: Bellavista, the Manager's villa (Iglesias Municipal Archive).

The second building, the Manager's House (Fig. 2), faces directly towards the Vittorio Emanuele Pit and it is an excellent example of Eclectic architecture. It features classical and aesthetic canons inspired by Pollack's 18th-century Villa Reale in Milan [33]: the Bellavista looks like a miniature of the Villa Reale with its C-shape formed by two advanced bodies connected by a central one.

The structure is made of stone masonry, iron beams and brick vaults, while openings were modified in the early 1900s with Art Nouveau accents that blend with former decorative elements and battlements, highlighting the Eclectic style of this building.

Along with these buildings, the Sella Pit (Fig. 3) represents the highest expression of a connubium between technical exaltation and Eclectic language. Made by the same designer, it consists of three bodies with a central block that emerges over the others, suggesting a threenaved cathedral. All of the bodies feature constructive solutions and technological approaches that are perfectly aligned with the most modern constructive experiences in Europe - such as Polonceau trusses - and that co-exist with the decorations. All of the façades feature arches, recesses and protrusions, oculi and holes, creating an elegant movement of light and shadows, strong and light elements and an apparently endless continuity of arched-windows on both sides. Similar to the Vittorio Emanuele Pit, there is a falsely embossed podium, Doric pilasters and adoptions from Post-Renaissance and Neoclassical styles that accentuate the Eclectic taste for these 'temples' of industrial production [34, 35].

Similar conclusions could be made about the building of the crane, located on the top of the former inclined plane. It shows a coexistence of the Eclectic style and the industrial purpose, thanks to a temple-like space whose holy cell housed the moving machinery, celebrating the technological function and the climax of industrial progress through a trabeation, pilasters, frames and evocative ornamental features.

The end of Pellegrini's management in 1875 marks the end of those industrial buildings where the Eclectic decorative presence goes along with a mature technical awareness, as seen in the buildings of the $1860 \mathrm{~s}-1870$ s. Since then, historical reminiscence gives way to a more concise and synthetic language where structural components prevail over ornamental 


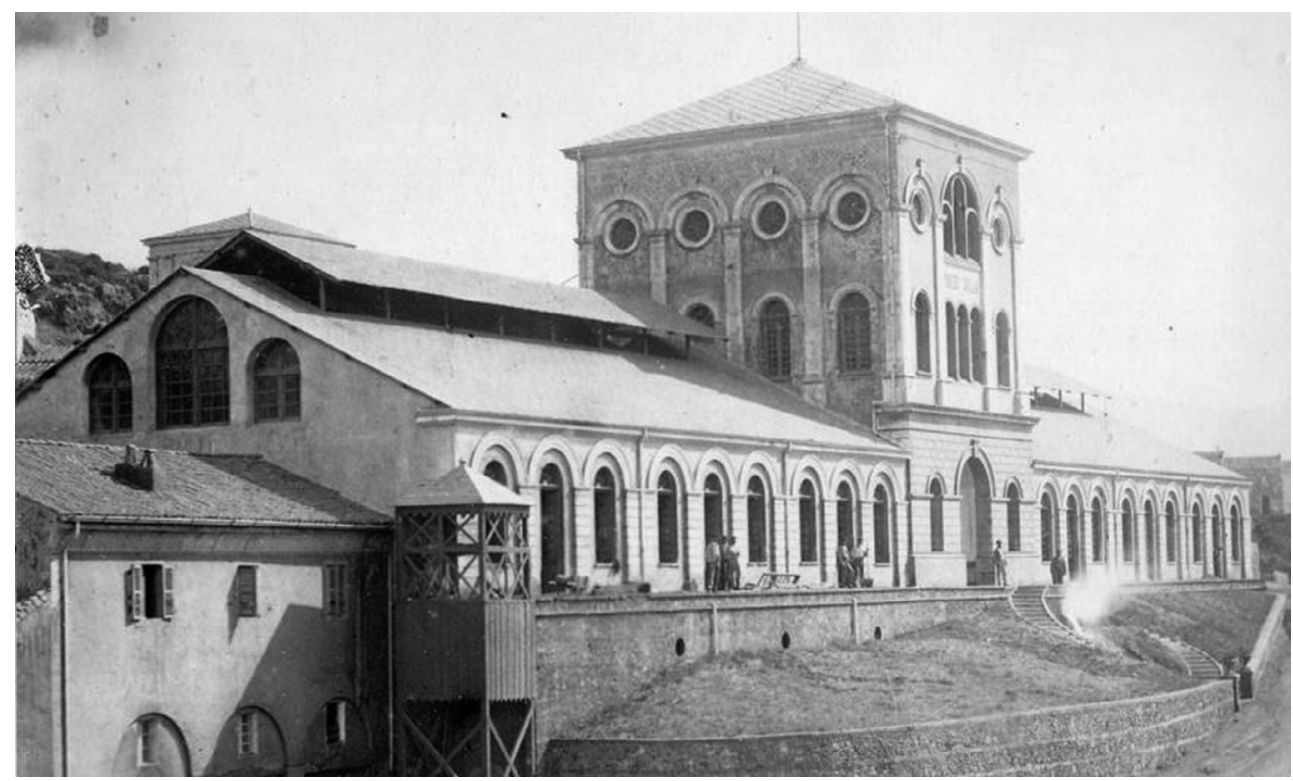

Figure 3: Sella Pit (Iglesias Municipal Archive).

and are often visible. For example, the Calamine, Pilla and Vittorio Emanuele washes feature a strong masonry mixed with arches, iron trusses with wooden boards and zinc shingles and extremely reduced decorative accents that are visible only in the corbels of the arches. The more time passes, the more austere and Spartan these buildings look, with a suppression of decorative elements, the introduction of apparently endless window series and the frequent presence of a pitched space with an oculus and three arches on the front. The Calamine Wash in Fig. 4 is the most structural of all with a strong presence of bearing elements, the absence of decorations and the exposition of metallic parts on each front: it demonstrates the prevalence of structure over masonry and how it sometimes completely replaces walls when it is more convenient and useful.

Pillars, cantilevers and arches have nothing in common with those of previous buildings, showing a linguistic change in the last decades of the 19th century.

In 1928, however, there is a slight return to a decorative style and aesthetical choices that recall the past. In such a large building, whose dimensions are still impressive today, we see a relation between its decorative accents and those of the surrounding Vittorio Emanuele Pit, the Bellavista Villa and the Sella Pit, maybe to refund the site for the suppression of the former Vittorio Emanuele Wash, replaced by the electrolysis plant. The use of concrete for structural parts such as trusses, pillars and beams, however, did not exclude the presence of brick masonry, of decorative frames around the openings, headers, false pilasters, embossing and decorations on the main façade. The electrolysis plant is the last of numerous great works that conclude the Classicist and Eclectic era in Monteponi. The 19th-century-style pediment, the small pillars and the plaque '1926' testify to the cohabitation of a humanistic approach to mining architecture and the early Modern Movement building criteria. 


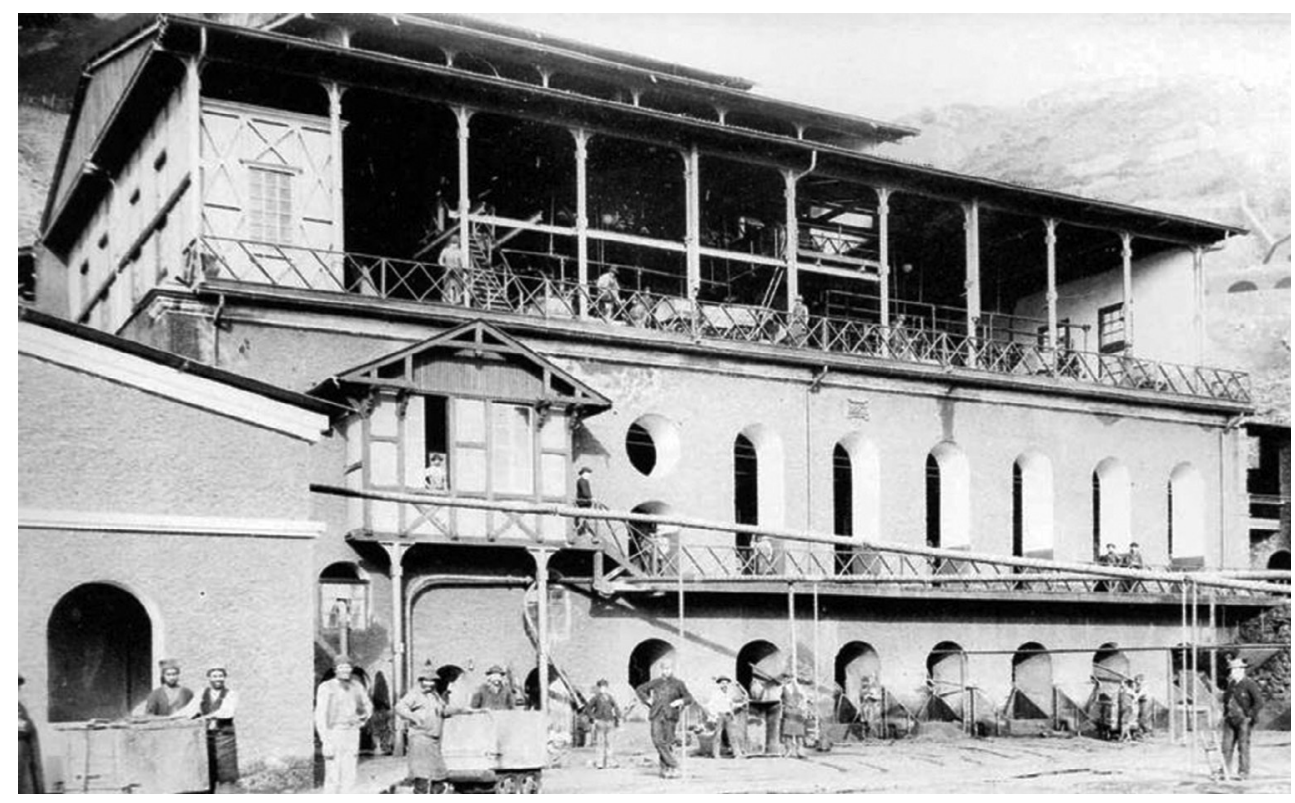

Figure 4: Calamine Wash in the 1890s (Iglesias Municipal Archive).

\section{CONCLUSIONS: PRESENT STATUS AND HYPOTHESIS OF REUSE}

Since the 1960s, when a general crisis broke down in metal and mineral trades, Monteponi suffered from economic and administrative issues. In order to avoid bankruptcy and to share energy costs and material supplies, the Monteponi Company first joined the Montevecchios in the 1950s and then the National Hydrocarbon Agency. However, despite investments in new productions of zinc and lead, it was clearly in decline and many factories and plants were progressively closed and dismantled until the 1990s [36]. An immediate consequence was the demolition and the abandonment of important buildings and infrastructure, such as the inclined plane, the railway, foundries of lead and cast iron, the electrolysis plant, the Calamine Wash, the Mameli Wash, workshops, the Bellavista and the main pits, Sella and Vittorio Emanuele. Auxiliary buildings, such as the Delaunay Hospital, the San Real Wash and the buildings in the lowest region, were left abandoned and exposed to weather and degradation just like the productive buildings. Today the situation has seriously worsened: many structures are near collapse and most of the decorative elements are completely or partially lost. This status of degradation consists primarily in collapse of bearing parts, such as concrete or wooden trusses, beams and pillars; the lack of big portions of masonry, such as the lead foundry and the electrolysis plant; the absence of roofs and coverings, which have left buildings completely exposed to biological, climatic and acid attacks; invasion of vegetation; presence of residue and scoria from mining and metallurgic works. The most eloquent cases are the electrolysis plant (Fig. 5), which was dismantled into many sections of masonry and has trusses that have almost collapsed, the foundries and the Calamine Wash, which is almost unrecognizable from its 1880 s' configuration. 


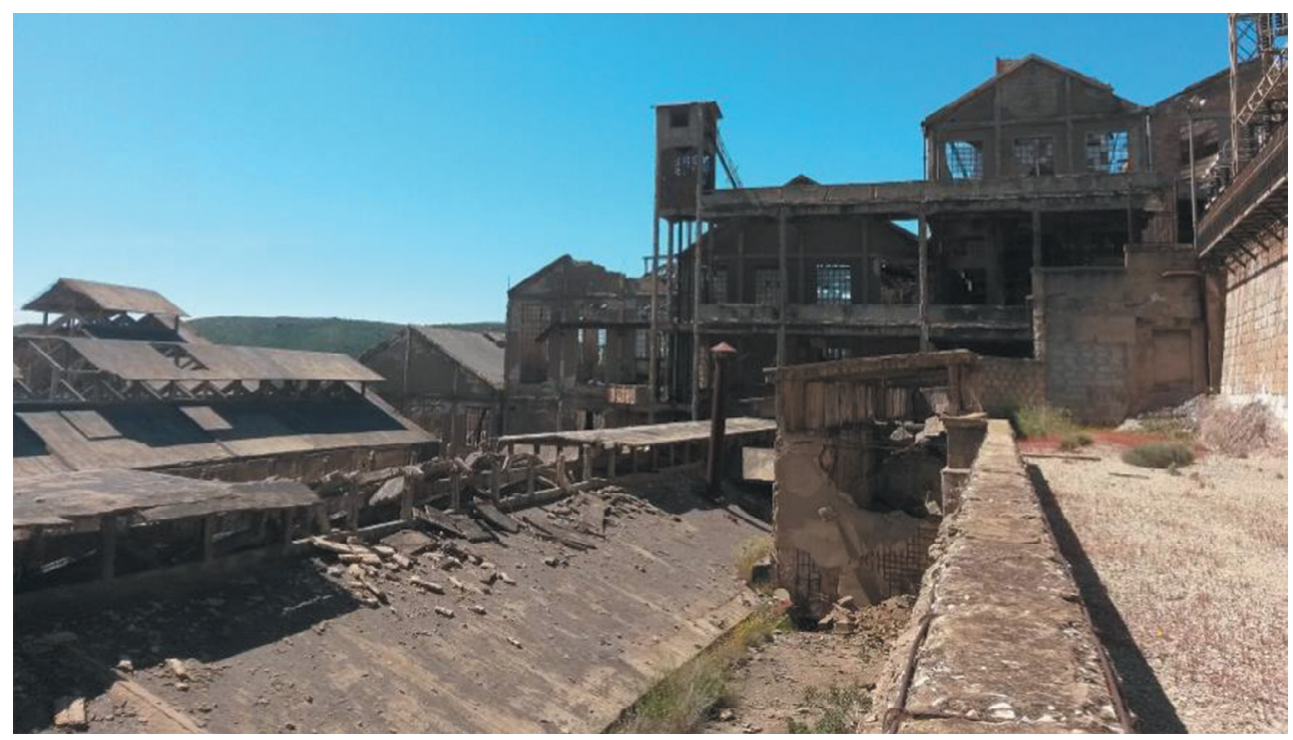

Figure 5: Electrolysis plant's collapsed roofs today (photo by the author).

The Vittorio Emanuele Pit's formal and evocative presence was unfortunately transformed with the addition of a squat concrete space which erased the original Neoclassical aura, making it difficult to recognize today. Only two buildings have been saved from ruin thanks to complex restorations, the Sella Pit and the Bellavista Villa: the former will be reopened to the public as a permanent collection of mining instruments, machineries and works and its external parts have already been renovated. The latter was restored in the late 1990s and today hosts congresses and public events on the ground floor.

In conclusion, I would like to briefly present a proposal to renovate and reuse the Calamine Wash as a permanent centre for studies and diagnosis on Monteponi's mining heritage: considering that the current building suffers from a lack of appropriate coverings and inner connections amongst its various levels, the first intervention would be the placement of steel structures from wall to wall to bear floors in order to divide the building into three levels: the lowest and the middle levels would be turned into studios and small workshop areas, while the top level would be turned into a terrace. Consequently the construction of a staircase to connect the ground and top floors would allow people to move inside the entire building. The project, which is still under review and is not yet completed, intends to leave the main façade untouched, using it as a curtain behind which there will be a new wall with openings all along the front. Thus, there would be a sort of long and narrow balcony displayed on the façade, which reveals what is behind through the existent windows. The north façade, which now features brick-filled arch windows, will be plastered, leaving the arch windows visible to recall the former openings of the 19th-century building. The whole system would look like a stage for the terrace on the top floor. Roofs, both in the main and secondary buildings, will be made with steel trusses - like the former Polonceau ones - with clay fillings and shingles; photovoltaic panels will be placed on the roof to provide energy. The existent appendices which were used as deposits, carpentry and garages - will be restored and converted into service buildings such as laboratories, pollution monitoring centres, prototypes deposits and workshops. 


\section{REFERENCES}

[1] Spanu, P.G., La Sardegna Vandalica e Bizantina. Storia della Sardegna 1: dalle origini al Settecento, eds. M. Brigaglia, A. Mastino \& G.G. Ortu, Laterza: Bari, p. 64, 2006.

[2] Ortu, G.G., I Giudicati: storia, governo e società. Storia della Sardegna 1: dalle origini al Settecento, eds. M. Brigaglia, A. Mastino \& G.G. Ortu, Laterza: Bari, pp. 97-98, 2006.

[3] Longhi, M.G. (ed.), Ferrero Della Marmora, A., Itinerario nell'Isola di Sardegna, Ilisso: Nuoro, p. 298, 1997.

[4] Ortu, G.G., La Sardegna dei Giudici, Edizioni Il Maestrale: Nuoro, p. 215, 2005.

[5] Manconi, F., Quintino Sella. Sulle condizioni dell'Industria mineraria in Sardegna, Ilisso: Nuoro, pp. 50-52, 1999.

[6] Ortu, G.G., I Giudicati: storia, governo e società. Storia della Sardegna 1: dalle origini al Settecento, eds. M. Brigaglia, A. Mastino \& G.G. Ortu, Laterza: Bari, p. 157, 2006.

[7] Manconi, F., Quintino Sella. Sulle condizioni dell'Industria mineraria in Sardegna, Ilisso: Nuoro, pp. 56-60, 1999.

[8] Ottelli, L., Monteponi. (Iglesias - Sardegna) Storia di eventi e di uomini di una grande miniera, Carlo Delfino: Sassari, p. 104, 2010.

[9] Casula, F.C., Breve Storia di Sardegna, Carlo Delfino: Sassari, p. 187, 1992.

[10] Manconi, F., Quintino Sella. Sulle condizioni dell'Industria mineraria in Sardegna, Ilisso: Nuoro, pp. 61-63, 1999.

[11] Manconi, F., Quintino Sella. Sulle condizioni dell'Industria mineraria in Sardegna, Ilisso: Nuoro, p. 67, 1999.

[12] Ottelli, L., Monteponi. (Iglesias - Sardegna) Storia di eventi e di uomini di una grande miniera, Carlo Delfino: Sassari, p. 105, 2010.

[13] Manconi, F., Quintino Sella. Sulle condizioni dell'Industria mineraria in Sardegna, Ilisso: Nuoro, p. 70, 1999.

[14] Manconi, F., Quintino Sella. Sulle condizioni dell'Industria mineraria in Sardegna, Ilisso: Nuoro, p. 71, 1999.

[15] Manconi, F., Quintino Sella. Sulle condizioni dell'Industria mineraria in Sardegna, Ilisso: Nuoro, p. 72, 1999.

[16] Ottelli, L., Monteponi. (Iglesias - Sardegna) Storia di eventi e di uomini di una grande miniera, Carlo Delfino: Sassari, p. 135, 2010.

[17] Ottelli, L., Monteponi. (Iglesias - Sardegna) Storia di eventi e di uomini di una grande miniera, Carlo Delfino: Sassari, p. 146, 2010.

[18] Ottelli, L., Monteponi. (Iglesias - Sardegna) Storia di eventi e di uomini di una grande miniera, Carlo Delfino: Sassari, p. 164, 2010.

[19] Manconi, F., Quintino Sella. Sulle condizioni dell'Industria mineraria in Sardegna, Ilisso: Nuoro, pp. 170-173, 1999.

[20] Ottelli, L., Monteponi (Iglesias - Sardegna) Storia di eventi e di uomini di una grande miniera, Carlo Delfino: Sassari, pp. 167-171, 2010.

[21] Ottelli, L., Monteponi (Iglesias - Sardegna) Storia di eventi e di uomini di una grande miniera, Carlo Delfino: Sassari, pp. 177-184, 2010.

[22] Zoppi, G., Atlante annesso al vol. IV delle memorie descrittive della carta geologica d'Italia. Memorie descrittive della carta geologica d'Italia. Descrizione geologico mineraria dell'Iglesiente (Sardegna) e Atlante, Vol. 4, ed. G. Zoppi, Tipografia Nazionale di Reggiani \& Co.: Rome, table 29, 1888. 
[23] Ottelli, L., Monteponi (Iglesias - Sardegna) Storia di eventi e di uomini di una grande miniera, Carlo Delfino: Sassari, p. 187, 2010.

[24] Società di Monteponi (eds), Società di Monteponi 1850 - 1950, Tipografia Vincenzo Bona: Turin, pp. 210-215, 1950.

[25] Ottelli, L., Monteponi (Iglesias - Sardegna) Storia di eventi e di uomini di una grande miniera, Carlo Delfino: Sassari, p. 197, 2010.

[26] Società di Monteponi (eds), Società di Monteponi 1850 - 1950, Tipografia Vincenzo Bona: Turin, pp. 215-217, 1950.

[27] Ottelli, L., Monteponi (Iglesias - Sardegna) Storia di eventi e di uomini di una grande miniera, Carlo Delfino: Sassari, pp. 197-200, 2010.

[28] Ottelli, L., Monteponi (Iglesias - Sardegna) Storia di eventi e di uomini di una grande miniera, Carlo Delfino: Sassari, pp. 220-221, 2010.

[29] Società di Monteponi (eds), Società di Monteponi 1850 - 1950, Tipografia Vincenzo Bona: Turin, pp. 230-240, 1950.

[30] Ottelli, L., Monteponi (Iglesias - Sardegna) Storia di eventi e di uomini di una grande miniera, Carlo Delfino: Sassari, pp. 226-230, 2010.

[31] Società di Monteponi (eds), Società di Monteponi 1850 - 1950, Tipografia Vincenzo Bona: Turin, pp. 242-250, 1950.

[32] Ottelli, L., Monteponi (Iglesias - Sardegna) Storia di eventi e di uomini di una grande miniera, Carlo Delfino: Sassari, pp. 54, 113, 127, 133, 2010.

[33] Lai, M.B., Olivo, P., Usai, G. (eds.), Eclettismo e Miniere. Riflessi europei nell'architettura e nella società sarda tra '800e '900. Catalogo della mostra, Graphic sas: Cagliari, p. 50, 2004.

[34] Iglesias Municipal Archive, Collection MP - MV, General Administration Serie, Inventory year 1873.

[35] Iglesias Municipal Archive, Collection MP - MV, Case No. 107, Dresser No.4, Drawer No. 1, Inventory No. 29.

[36] Ottelli, L., Monteponi (Iglesias - Sardegna) Storia di eventi e di uomini di una grande miniera, Carlo Delfino: Sassari, pp. 271-302, 2010. 